\title{
AL-BUGHOT DALAM PERSPEKTIF MAZHAB FIQH
}

\author{
Syafi'i \\ Institut Agama Islam Salahuddin Al-Ayyuby ( INISA ) \\ Jln Sultan Hasanudin No 203 Tambun-Bekasi, Jawa Barat 17510 \\ Email: peisyafii14@yahoo.co.id
}

\begin{abstract}
Al-Bughot based on the Perspective of Fiqh Madhhab. One of the actual discussions currently is about traitor to the nation. Whom are daring to betray their nation with violence and military power against security forces and oppose the government, moreover, they are arrogantly daring to proclaim the establishment of a new state with a new authority as well. In this case, Islam gives a chance to their adherents to do their best to take appropriate action as needed. It seems Allah has deliberately given Muslims an opportunity to act according to their reasoning ability, under the condition that it is not against the naskh in Quran and Hadith. This action is called Ijtihad. It is certainly that there will be a contradiction between the policy makers in the act of Ijtihad. Thus, there will be a contradiction between Mujtahid scholars, including the four well known Mujtahid Imams, in the case of Bughot as well.
\end{abstract}

Keywords: Bughot, madhhab, syaukah, ta'wil and hudud.

Abstrak: $\quad$ Al-Bughot Dalam Perspektif Mazhab Figh. Salah satu pembahasan yang aktual pada saat sekarang adalah masalah penghianat bangsa. Mereka dengan berani menghinati bangsa dengan kekerasan, Dengan kekuatan militer yang dimiliki, mereka berani melawan pihak keamanan dan akhirnya mereka menentang pemerintahan, bahkan mereka dengan congkak berani memproklamirkan pembentukan negara baru dengan kekuasaan baru pula. Dalam hal seperti ini, Islam memberi kesempatan pada pemeluknya untuk melakukan hal-hal yang terbaik untuk menentukan tindakan apa yang dibutuhkan. Sepertinya ada kesengajaan dari Allah swt. untuk memberi kesempatan kepada pemeluk Islam untuk bertindak sesuai kemampuan nalarnya, dengan catatan tidak bertentangan dengan nas qur'ani dan hadis. inilah yang disebut dengan tindakan ijtihadi. Dalam tindakan ijtihadi sudah dapat dipastikan akan terjadi kontradiksi antara para penentu kebijakan, Karenanya dalam masalah bughot pun terdapat kontradiksi antara para ulama mujtahid, bahkan termasuk empat imam mujtahid yang terkemuka dalam bidang hukum.

Kata Kunci: Bughot, mazhab, syaukah, ta'wil dan hudud 


\section{Pedahuluan}

Lafaz al-bughot adalah bentuk jamak dari isim fail baghin yang berasal dari lafaz bagho-yabghi yang mengandung arti mencari, durhaka, berpaling, melampaui batas atau melawan dan zholim. ,dengan demikian al-bughot adalah sekelompok orang yang berdurhaka dengan mengadakan perlawanan.

Dalam pengertian al-Bughot ulama mazhab fiqh berbeda pendapat dan ini berdampak kepada pembahasan yang berkaitan dengan masalah-masalah yang timbul disekitar bughot itu sendiri.

Menurut Hanafiyah bahwa bughot mengandung pengertian mereka yang keluar untuk tidak taat kepada imam yang hak tanpa hak. ${ }^{1}$ Mereka memiliki syaukah atau kekuatan senjata dan menyalahi pendapat mayoritas muslim dalam masalah hukum dengan cara tawil atau sebab musababnya serta memproklamirkan kepada negara lain, seperti halnya kaum Khowarij yang keluar dari Ali bin Abi Tholib sebgai pemimpin yang sah. ${ }^{2}$

Malikiyah berpendapat ${ }^{3}$ bahwa bughot adalah suatu firkoh atau kelompok dari kaum muslimin yang telah menyalahi imam atau wakilnya yang terpilih berdasarkan kesepakantan ummat dengan tujuan mencegah hak Allah swt dan hak Adam ${ }^{4}$.

Mazhab Syafi'i berkomntar ${ }^{5}$ tentang definisi bughot adalah mereka yang menyalahi imam yang adil dan mereka keluar dari taat kepadanya dengan cara mencegah dari kewajiban yang dibebankan kepadanya dengan syarat mereka memiliki kekuatan senjata dan ingin merubahnya serta adanya pemimpin diantara mereka. Jadi menurut ulama Syafi'iyah bughat adalah pemberontakan dari suatu kelompok orang (jama'ah), yang mempunyai kekuatan (syaukah) dan pemimpin yang ditaati (muthaa'), dengan keinginan merubah (ta`wil) dengan jalan merusak (fasid).

\footnotetext{
${ }^{1}$ Abdul Qodir Auda, at-Tasyri' al Jina'T, Juz ke dua, h.673

${ }^{2}$ Wahbah Zuhaily, al-fiqh al-Islami wa Adillatuha, Juz ke enam Bairut, Darul Fikr,. Cet. Ke tiga.1989 h. 142

${ }^{3}$ Imam Dasuqy al-Malikiyah, Hasiyah Dasuqy, Juz ke enam, h.276

${ }^{4}$ Hak Allah adalah hak jama'ah atau hak ummat semdangkan hak adam adalah hak perorangan.

${ }^{5}$ Imam al-Ghozaly, Al-Wasith fil Mazhab, Dar al-Gislan, , 1997, Juz. Ke enam h.415
} 
Sedangkan mazhab Hanbali berpendpat ${ }^{6}$ bahwa bughot adalah mereka yang keluar dari taat kepada imam yang adil.

Dengan demikian bahwa bughot itu adalah sekelompok ummat muslim yang berkeinginan untuk mengadakan perlawanan kepada imam atau pemerintahan yang sah dengan cara melakukan tindakan makar dan tindakan ini dilakukan dengan terorganisir dibawah satu kepemimpinan.

Dari beberapa definisi tentang bughot tersebut dapat ditentukan bahwa tidaklah dikatakan tindakan bughot jika tindakan tersebut belum memenuhi kriteria-kriteria seperti di bawah ini, antara lain: (1) Memiliki kekuatan dengan banyaknya pengikut yang disertai dengan perlengkapan senjata. (2)Memiliki alasan kenapa mereka melakukan tindakan makar dan berkeinginan untuk keluar dari kepemimpinan yang ada atao mereka menentang kebijakan pemerintahan dengan menolak kewajiban yang diperintahkan kepadanya. (3) Memiliki pemimpin diantara mereka yang senantiasa di taati.

Dalam hal ini Imam Mawardi berpendapat ${ }^{7}$ bahwa tindakan makar dapat dikatakan tindakan bughot jika tindakan tersebut telah memenuhi empat syarat antara lain: (a)Mereka memiliki jumlah yang besar sehingga tidak mungkin dikalahkan melainkan harus dengan jalan peperangan (b)Mereka mengasingkan atau keluar dari pemerintahan yang adil. Seperti kelompok perang Jamal. (c)Mereka menentang pemerintahan yang sah dengan cara ta'wil atau mengajak kepada sebab-sebab untuk keluar dari pemerintahan yang sah. Seperti kasus perang Jamal dimana mereka menuntut kepada Saidina Ali agar mengusut siapa pembunuh Usman bin Affan yang sebenarnya. (d) Mereka memiliki imam atau pemimpin yang harus ditaati dan patuh akan perintahnya

Dari definisi di atas juga dapat dikatakan, bahwa tindakan makar dapat dikatakan tindakan bughot jika telah memenuhi tiga rukun ${ }^{8}$ antara lain: Pertama, Tindakannya dapat menimbulkan pemberontakan

${ }^{6}$ Syiekh al-'Alamah Mansur bin Yunus al-Hanabilah, Kasyaful Qina - Matan al-iqna' Bairut, Dar al-Fikr, 1983, Juz. Ke enam h.158

${ }^{7}$ Syafi'i, muqoronatil mazabib al-arba'ah wa mazhbab ja'fari fil hudud wal qisos wa tathbiquha fi Indonesia, h. 219

${ }^{8}$ Nurul Irfan dan Masyrofah, Fiqh Jinayah, PT. Amzah, Jakarta. 2013 h.62, lihat juga dalam kitab karangan Ahmad Fathy Bahnsy, al-Masuliyah al-Jinaiyah fi al-Fiqh al-Islamiyah, Dar al-Syuruf, .1984 h.93 
kepada pemimpin yang sah. Biasanya para pemberontak tidak mau mematuhi kewajibannya daningin menentangnya. Kedua, Tindakannya dilakukan secara demonstratife taitu dengan tindakan kekerasan yang didukung dengan pasilitas senjata. Ketiga, Tindakannya termasuk perbuatan tindak pidana, seperti membuat kekacauan dengan maksud menggulingkan pemrintahan yang sah.

Dari syarat-syarat dan rukun-rukun tersebut di atas dapat dikatakan bahwa sekalipun bughot merupakan tindakan kekerasan yang dapat merusak negara dan ummat, namun dalam memberantas kaum pemberontak tidak serta-merta memerangi dan mengusir mereka begitu saja, tapi harus dengan perhitungan dan pertimbangan yang sangat teliti. Hal ini dilakukan karena tindakan kekerasan seperti pemberontakan itu baru dapat dikatakan tindakan bughot jika telah memiliki beberapa kritiria tertentu seperti telah disebutkan di atas, kecuali syarat nomer ke empat para ulama berbeda pandangan apakah imam merupakan syarat atau bukan.

Menurut pendapat pertama bahwa imam bukanlah merupakan syarat dari tindakan bughot. Inilah pendapat dari mayoritas ulama termasuk pengikut mazhab Syafi'i. Hal ini pernah terjadi pada pristiwa perang jamal dan perang siffin, dimana Ali bin Abi Tholib memerangi mereka karena dianggap sebagai kelompok bughot.

Sementara pendapat kedua adalah bahwa imam adalah merupakan syarat dari tindakan bughot. Tidak dapat dikatakan kaum bughot jika diantara mereka tidak memiliki imam atau pemimpin. Ini adalah pendapat dari mazhab Maliki. Mereka mengatakan kaum bughot adalah setiap orang yang dapat mencegah untuk taat kepada imam baik dengan kekerasan maupun tidak, selain ma'siat kepada Allah swt. bahkan mazhab Malik berpendapat bahwa tindakan bughot itu dapat dilakukan oleh seorang diri. ${ }^{9}$

\section{Pembahasan}

Dalam syari'at Islam dijelaskan bahwa tindak kejahatan dapat diklasifikasikan kepada lima katagori yang mana setiap tindakan tersebut memiliki kritiria dan sanksi yang berbeda antara lain: (1) Tindak kejahatan dimana sanksinya telah ditentuka oleh Allah swt

\footnotetext{
${ }^{9}$ Imam Syafi;i, Abdullah Muhammad bin Idris, al-Umm. Bairut,Dar al-Fikr.tth. h. 219
} 
dan rosul Nya. Tindakan seperti ini disebut dalam fiqh Islam dengan nama jarimah hudud. (2)Tindak kejahatan dimana sanksinya harus sesuai seperti apa yang telah diperbuat. Tindakan ini disebut dengan istilah jarimah qisos. (3)Tindakan kejahatan dimana sanksinya tidak ditentuka oleh Allah swt karena tidak tertera dalam al-qur' an maupun al-Hadist, namun sanksinya akan ditentukan oleh manusia, dalam hal ini adalah seorang hakim dalam pengadilan. Tindakan seperti ini disebut istilah jarimah ta'zir. (4)Tindak kejahatan dimana sanksinya merupakan sanksi tambahan atau pelengkap bagi jarimah hudud dan qisas, namun merupakan sanksi pokok bagi tindak jarimah tertentu, dan sanksinya ini berupa denda, bukan sanksi yang dapat menyakitkan badan. Tindakan seperti ini disebut dengan istilah jarimah diat. (5) Tindak kejahan dimana sanksinya merupakan sanksi pelengkap bagi jarimah hudud dan qisas, namun merupakan sanksi pokok bagi tindakan tertentu. Tindakan seperti ini disebut dengan istilah jarimah kafarat.

Pembagian tindak kejahatan seperti di atas merupakan pendapat sebagian ulama mujtahid, namun sebagian lagi berpendapat bahwa tindak kejahatan hanya terdiri dari tiga katagori yaitu jarimah hudud, jarimah qisos dan jarimah ta'zir, sementara diat dan kafarat bukanlah termasuk tindak kejahatan. Bahkan sebagian ulama berpendapat bahwa kifarat itu bukanlah termasuk dalam katagori sanksi atau hukuman, karena kifarat tekananannya kepada ibadah seperti kafarat puasa, pemberian makan kepada fakir-miskin dan lainnya, sementara sanksi adalah membuat badan atau jasad teraniaya dan terluka akibat dari sanksi tersebut.

Dengan demikian yang termasuk dalam katagori tindak kejahatan yang sanksinya telah ditentuka oleh nas adalah tindak kejahatan tertentu saja termasuk di dalamnya adalah jarimah bughot. Ulama mazhab empat berpendapat bahwa jarimah bughot adalah termasuk dalam katagori jarimah hudud dengan hukuman yang telah ditentukan oleh nas yang qot'i baik al-Qur' an maupun al-Hadits. ${ }^{10}$

Dalam jarimah bughot Allah swt. telah berfirman lewat al-Qur'an yang terdapat pada surat al-Hujrat pada ayat ke 9 yang berbunyi:

${ }^{10}$ Imam Syafi;i, Abdullah Muhammad bin Idris, al-Umm. Bairut,Dar al-Fikr.tth.h. 216 


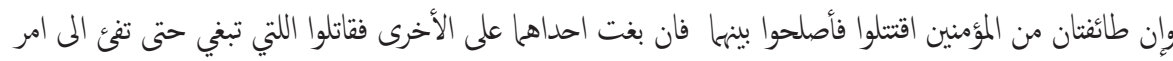

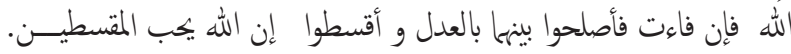

Dan jika dua golongan dari orang-orang mukmin berperang, maka damaikanlah antara keduanya. Jika salah satu dari kedua golongan itu berbuat aniaya (zalim) maka perangilah golongan yang berbuat aniaya itu sehingga golongan itu kembali kepada perintah Allah ( Qs al-Hujrat 49 : 9)

Dalam tafsir Qurthubi disebutkan, ${ }^{11}$ Sahabat Nabi yang bernama Qotadah pernah meriwayatkan bahwa ada dua orang dari kaum anshor yang saling merebuttkan haknya masing-masing, berkata yang satu kepada yang lainnya 'Aku akan mengmabil hak kekayaanku sebab aku memilki keluarga yang banyak'. Kemudian yang lain datang dan mengadukan masalahnya kepada Rosulullahi saw. namun Rosul enggan menyelesaikannya, sampai akhirnya terjadi perkelahian diantara keduanya yang diawali dengan saling memukul, saling menyambit dan saling menggunakan pedang. Maka turunlah ayat ini sebagai jawaban dan penyelesaian antara keduanya. Dalam riwayat Kalbi diceritakan bahwa terjadi perkelahian antara Sumair dan Hatib sampai Hatib terbunuh yang keduanya berlainan suku, maka terjadilah peperangan antara dua suku besar yaitu suku Aus dengan suku Khorroj, sehingga permasalahan ini sampai kepada Rosulullahi saw. dan turunlah ayat ini.

Dalam kitab al-Masuliyah al-Jinaiyah, Ahmad Fathi menyebutkan pendapat Imam ibnu al-Araby yang menyebutkan ada empat riwayat tentang asbabu nuzul ayat bughot di atas ${ }^{12}$

Dalam kitab Fathul Wahhab Imam Syaikhul Islam Zakariyya Al-Anshari mengatakan, Dalam ayat ini memang tidak disebut 'memberontak kepada imam' secara sharih, akan tetapi ayat tersebut telah mencakupnya berdasarkan keumuman ayatnya, atau karena ayat tersebut menuntutnya. Sebab jika perang dituntut karena kezaliman satu golongan atas golongan lain, maka kezaliman satu golongan atas imam tentu lebih dituntut lagi.

Dalam hadis diterangkan dengan jelas tentang hukuman bagi

\footnotetext{
${ }^{11}$ Imam Qurthubi, al-Jami' li Abkeamil al-Qur'an, Jilid. 16, Bairut: Dar al-Kitab, 2000,h,207

${ }^{12}$ Ahmad Fathy Bahnsy, al-Masuliyah al-Jinaiyah fi al-Figh al-Islamiyah, Dar al-Syuruf,.1984, h.
} 91-92. 
kaum muslimin yang melakukan tindakan bughot antara lain bahwa Rosulullah saw, pernah bersabda: “Barangsiapa yang keluar dari ketaatan (kepada khalifah) dan memisahkan diri dari jamaah kemudian mati, maka matinya adalah dalam keadaan mati jahiliyyah." (HR. Muslim).

Hadits di atas memperjelas hukum bughot dimana dalam nash al-qur' an diungkapkan secara global saja, tidak secara rinci maka Rosulullah memperjelasnya, inilah pungsi hadits terhadap al-Qur'an.

Dari dua dalil di atas para Imam mujtahidin sepakat, apabila suatu kelompok orang berkeinginan untuk mengadakan tindakan makar terhadap negara dengan cukup alasan, maka diperbolehkan kepada kepala negara memerangi mereka sampai mereka kembali kepada kebenaran. Apabila mereka menyadari kesalahannya, hendaklah dihentikan penumpasannya, jangan diperangi. Jadi menumpas kaum pemberontak adalah wajib karena dari segi perbuatan sudah menyalahi hukum Allah, maka dia termasuk pada perbuatan maksiat dan oleh karenanya terhadap pelakunya dikenakan ancaman yang bersifat fisik di dunia, dan tindakan tersebut termasuk dalam katagori tindak pidana jinayah atau jarimah hudud. ${ }^{13}$

Dalam menangani kaum bughot tidak boleh serta merta memusuhi mereka dengan cara kasar seperti mengusir dan menangkap mereka apalagi langsung memerangi mereka secara membabi buta tanpa perhitungan terlebih dahulu. Tindakan seperti itu bukanlah manusiawi dan tidak Islami. Karena itu syari'at Islam telah memberikan garisgaris dalam mengahadapi kaum bughot.

Pertama yang harus dilakukan oleh pemerintah dalam menghadapi kaum bughot harus mengadakan negosiasi terhadap kaum bughot tersebut dengan cara mengirim delegasi. Hal ini dilakukan untuk mengadakan perundingan atau perdamaian. Dalam negoisasi tersebut dapat diungkapkan kenapa kalian mengadakan tindakan bughot?, Apa yang kalian inginkan dengan tindakan bughot ini? dan seterusnya. Jika negoisasi ini mengalami kemandekan dan jalan

\footnotetext{
${ }^{13}$ Hudud adalah tindak kejahatan terhadap fisik atau badan seseorang yang telah ditentukan sanksinya oleh syari’ baik Allah swt maupun Rosulullah saw. dan pelaksanaan hukumnya di lakukan di dunia. Jumhur ulama sepakat jika telah dilaksanakan sanksi hudud di dunia maka tidak ada lagi sanksi akhirat.
} 
buntu, maka pemerintah menginformasikan kepada kaum bughot bahwa pihak pemerintah akan mengdakan serangan dan menyatakan perang terhadap mereka dalam waktu dekat. Kemudian pemerintah menentukan waktu dan lokasinya.

Hal ini dilakukan untuk memberi kesempatan kepada kaum bughot untuk kembali bergabung. Inilah yang dimaksud dari firman allah swt '...maka damaikanlah diantara keduanya ,,', Potongan ayat ini memberi penjelasan bahwa dalam menghadapi kaum bughot terlebih dahulu harus mengadakan perdamaian atau negoisasi. Hal ini pula yang pernah dilakukan oleh Ali bin Abi Tholib, sebagai khulafah Rosidin dan panglima tertinggi pada saat itu, dalam menghadapi kaum Khowarij yang mengadakan pemberontakan kepadanya. Dan dengan lokasi peperangan yang ditentukan akan lebih menghindarkan banyak korban jiwa yang berjatuhan serta menghindari kerusakan pasilitas umum maupun pribadi.

Imam Abu Hanifah, sebagai pendiri mazhab hanafiyah berkomentar bahwa sebelum mengadakan peperangan melawan kaum bughot maka pemerintah berkewajiban mengadakan ishlah terlebih dahulu. ${ }^{14}$ Hal ini sesuai dengan ayat al-Qur'an. Dan kholifah Ali bin Abi Tholib pun pernah menyuruh kepada Abd bin Abbas untuk mengadakan ishlah dengan Muawiyah bin Abi Sofyan sebelum terjadi perang siffin.

Syaikh Abu Ishak menjelaskan ${ }^{15}$ bahwa pemerintah berkewajiban memberi kesempatan kepada kaum bughot untuk dapat bertaubat dan kembali kepada pemerintahan yang sah. Kesempatan ini harus diberi waktu sampai tiga hari lamanya. Namun kalau sudah diberi tempo tiga hari masih tetap mengadakan tindakan makar maka pemerintah berkewajiban untuk mengadakan perang.

Dalam pada itu Imam Qofal berkomntar ${ }^{16}$ bahwa ayat tersebut memberikan penjelasan kepada kita bahwa ada lima pelajaran yang dapat di ambil antara lain: (1)Kaum bughot tidak keluar dari Islam atau tetap beriman (2)Kaum bughot harus di perangi (3) Kaum bughot yang kembali bergabung tidak boleh di perangi (4)Kaum bughot tidak berkewajiban menanggung sesuatu yang lenyap pada peperangan

${ }^{14}$ Syeikh Nawawi, al-Majmu' Syarah Muhajjab Li Syairoji, Bairut Libanon, 1996 h. 34 juz. 21.

${ }^{15}$ Syeikh Nawawi, al-Majmu' Syarah Mubajjab Li Syairoji, h. 35.

${ }^{16}$ Syeikh Nawawi, al-Majmu' Syarah Muhajjab Li Syairoji, h. 33. 
tersebut (5)Pemerintah berkewajiban untuk memerangi setiap orang yang menentangnya.

Dari keterangan Imam Qofal jelaslah bahwa kaum bughot itu masih memiliki keimanan kepada Allah swt, karenanya mereka tidak boleh disamakan dengan orang kafir dengan cara tidak memberikan kesempatan untuk bertaubat dan kembali kepada pemerintahan yang sah. Namun demikian jika mereka tidak ada tanda-tanda bertaubat maka dengan rasa terpaksa pemerintah harus memerangi mereka sekalipun mereka masih dalam katagori orang yang beriman.

Dalam masalah bughot terdapat pembahasan imam atau pemimpin tertinggi. Hal ini terkait dengan pertanyaan kenapa kaum bughot mengadakan pemberontakan terhadap pemerintahan yang sah, bisa jadi mereka menilai bahwa imam atau pemimpin dalam pemerintahan yang sah dianggap menyimpang atau ada masalah lain dengan seorang imam tersebut. Karenanya perlu ada pembahasan masalah imam atau pemimpin.

Abdul Qodir Audah berkomentar bahwa yang dimaksud imam atau khalifah, bukanlah presiden atau raja atau kepala negara yang bukan negara Islam (Daulah Islamiyah/Khilafah). Menurutnya Imam adalah pemimpin tertinggi (kepala) dari Negara Islam (ra is ad-dawlah al-islamiyah al-a'la), atau orang yang mewakilinya.

Sementara itu ada ulama yang mengatakan bahwa imam itu adalah pemimpin tertinggi di suatu Negara Islam \{rois daulah Islamiyah al-'ala) atau orang yang mewakili dari kekuasaannya baik mentri, hakim atau lainnya. Sebagian lagi berpendapat bahwa imam adalah pempmpin tertinggi di suatu negara Islam dimana tidak ada pemimpin di atanya (dialah yang tertinggi), ${ }^{17}$

\section{Pandangan Ulama tentang Hukum Bughot}

Ulama sepakat bahwa dalil yang dijadikan dasar tentang larangan melakukan tindakan bughot adalah surat al-Hujrat ayat ke 9 dan Ulama mazhab, baik dari kalangan Sunni maupun Syi'ah mengatakan bahwa tindakan bughot adalah haram dan sanksinya adalah hukuman mati.

${ }^{17}$ Syafi'I, desertasi doctoral, muqoronah mazahib al-arba'an wa mahab ja'fari fi hudud wa qisos wa tathbiku ahkamuha fi Indonesia, h. 218. 
Hukuman bagi tindakan bughot yang telah disebutkan dalam al-Qur'an telah di ta'kid oleh al-Hadits. Rosulullah saw. pernah berkomentar 'Siapa yang memberikan persetujuan dan kesetiaanya kepada imam (penguasa Negara), maka taatilah dia sedapat mungkin. Kalau datang orang lain memperseketakan kekuasaan imam maka potonglah leher orang tersebut'. ${ }^{18}$ Dalam riwayat lain dikatakan bahwa Rosulullah saw. bersabda 'Siapa yang mendatangimu -sedang urusanmu berada di tangan mereka (pemimpin), dan mereka ingin merusak kekuasaanmu serta akan memprak porandakan jamaahmu, maka bunuhlah merekaitu. (HR.Muslim) $)^{\prime 19}$

Dari hadits di atas dapat dikatakan bahwa hukum Islam dengan sengaja telah mengambil tindakan tegas terhadap bughot, karena kalau tidak demikian maka akan timbul kekacauan yang akan mengganggu kesetabilan Negara, akan terjadi tindakan kejahatan lainnya sehingga ketentraman dan kenyamanan masyarakat akan terganggu. Karena itu suatu keharusan bagi ajaran Islam untuk menindak keras terhadap tindakan bughot dengan hukuman mati.

Selain hukuman bagi pelaku bughot yang telah di jelaskan oleh al-qur'an dan Hadis tersebut, namun ayat tersebut tidak menjelaskan masalah imam atau pemimpin, tidak dijelaskan tentang pemimpin yang bagaimana sehingga kaum muslimin mengadakan tindakan bughot atau melakukan tindakan kekerasan, apakah pemimpin yang sah tersebut melakukan ke zoliman atau ada sebab lain. Dari sinilah para ulama berbeda pandangan dalam hal tindakan bughot tersebut.

Sebagian ulama berpendapat bahwa tindakan bughot tidaklah dibenarkan. Hal ini sesuai dengan hadis yang berbunyi Dari Abu Hurairah r.a., katanya; "Rasulullah s.a.w. bersabda: "Barangsiapa yang taat kepadaku, maka ia telah mentaati Allah dan barangsiapa yang bermaksiat kepadaku, maka ia telah bermaksiat pula kepada Allah dan barangsiapa yang mentaati amir -pemegang pemerintahan-, maka ia benar-benar mentaati saya dan barangsiapa yang bermaksiat kepada amir, maka ia benar-benar bermaksiat kepada saya." (Muttafaq 'alaih)

Hadis di atas menjelaskan keharusan kaum muslimin taat dan

\footnotetext{
${ }^{18}$ Ahmad Hanafi, Azas-Azas Hukum Pidana Islam, Jakarta,Bulan Bintang, .2002, h.207

${ }^{19}$ Rahmat Hakim, Hukum Pidana Islam, Bandung, Pustaka Setia,. 2000. h.110
} 
tunduk kepada pemimpinnya. Dalam riwayat lain disebutkan bahwa sekalipun pemimpin tersebut melakukan ketidak adilan maka kaum muslimin harus tetap tunduk kepada pemimpinnya. Daan tidak boleh mengadakan tindakan makar atau pembberontakan. Hal ini sesuai dengan hadis Nabi 'Dari Ummu Salamah dari Nabi, Beliau bersabda '... mereka bertanya, ya Rosulallah bolehkah kita memerangi mereka (kaum bughot)? Rosulullah menjawab, Jangan selama mereka melaksanakan solat'. ${ }^{20}$

Imam Mawardi, salah satu murid Imam syafi'i berkomentar dalam kitab al-Hawi al-Kabir, bahwa al-Qur'an dan al-Hadis serta Ijma telah membolehkan memerangi kaum bughot. ${ }^{21}$ Namun demikian Imam Syafi'i tidak membenarkan untuk memerangi kaum bughot tanpa memperhatikan sebab dan dampaknya. Beliau berkata dalam kitab al$\mathrm{Um},{ }^{22}$ jika ada suatu kaum yang keluar dan menjauhkan dari jama'ah, maka kita tidak boleh memeranginya, karena ada riwayat yang sampai kapada saya bahwa Ali bin Abi Tholib pernah mendengar seseorang yang mangatakan 'tiada hukum melainkan milik Allah swt' di dekat masjid. lalu Ali berkata kalimat tersebut adalah benar adanya, namun dalam hal ini ada kekeliruan, dan kami tidak mencegah kamu untuk menyebutkannya di sekitar masjid dan kami tidak akan memerangi kamu.

Imam Qopal berpendapat ${ }^{23}$ bahwa mereka yang keluar dari pemerintahan yang sah serta telah memenuhi syarat-syaratnya dapat dikatakan kaum bughot sekalipun imam yang sah tersebut tidak adil.

Pernyataan Imam Qopal tersebut memberi isyarat bahwa melakukan tindakan makar terhadap pemerintahan yang sah tidaklah dibenarkan dalam ajaran Islam, karena tindakan tersebut termasuk dalam katagori tindakan bughot yang harus diberantas dan diperangi. Hal ini sesuai dengan hadis riwayat dari Ibnu Abbas dari Nabi, Ia bersabda 'Siapa yang membenci sesuatu dari pemimpinnya maka hendaklah dia bersabar, karena barangsiapa yang keluar sejengkal saja dari ketaatan kepada imam atau pemimpin maka ia mati dalam

\footnotetext{
${ }^{20}$ Rahmat Hakim,Hukum Pidana Islam. h.1222.

${ }^{21}$ Imam Mawardi, al-Hawi al-Kabir, Dar Fikr, Bairut Libanon, 1994, Juz 16 h.258.

${ }^{22}$ Imam Syafi'i, Abdullah Muhammad bin Idris, Al-Um, Bairut, Dar al-Fikr Juz. Ke lima. h. 364 .

${ }^{23}$ Syeikh Nawawi, Mahyuddin, al-Majmu' Syarah Mubajjab Li Syairoji, Jeddah,Maktabah alIrsyad, Juz. 21 t.th., h. 33
} 
keadaan mati jahiliyah. ${ }^{24}$

Imam Syafi'i dalam kitabnya al-Um menjelaskan bahwa Allah swt memerintahkan tindakan perdamaian sebelum mengadakan perang terhadap kaum bughot dan tidak menyebutkan jiwa dan harta. Ini menunjukan bahwa peperangan akan berdampak kepada banyaknya korban jiwa, banyak yang terluka bahkan akan banyak kehilangan harta benda. Pandangan Imam Syafi'i seperti ini telah mengandung makna bahwa tindakan bughot adalah tindakan yang tidak dibenarkan dan harus dihindari..

Dalam kaidah fiqhiyah dipaparkan bahwa 'menghindari kerusakan adalah lebih baik daripada mencari kebaikan'. Dari kaidah ini mayoritas ulama berpandangan bahwa tindakan bughot tidaklah dibenarkan bahkan diharamkan, hal ini disebabkan karena tindakan tersebut mendatangkan kerusakan, baik pasilitas umum maupu pribadi, juga berdampak kepada banyaknya korban jiwa dari kedua belah pihak, bahkan korban jiwa dari rakyat yang tidak berdosa, sementara keinginan dari kaum bughot yaitu pemimpin yang adil belum pasti diperolehnya. Keadaan seperti itu dapat terlihat dari tindakan makar kaum ISIS pada awal abad $21 \mathrm{M}$. dimana pemerintahan Libya, Surya dan Turki memerangi kaum pemberotak tersebut, peperangan ini mengakibatkan perang saudara dan menelan banyak korban jiwa dan porak porandanya pasilitas umum dan pribadi, Inilah dampak tindakan bughot. Karenanya bughot merupakan tindakan yang tilarang keras dalam ajaran islam.

Namun demikian ada ulama yang membolehkan tindakan bughot, tentu dengan kriteria yang ketat, sehingga tindakan bughot tersebut sesuai dengan syari'at Islam. Hal ini sesuai dengan firman Allah swt, surat al-Hujrat pada ayat ke 9. Ayat tersebut menjelaskan adanya kaum bughot dan cara menghadapinya. Jika Allah swt telah melarang tindakan bughot maka secara tegas Allah swt. melarangnya tanpa menjelaskan cara menangani kaum bughot tersebut. Dari sini ulama berpendapat bahwa tindakan buhgot itu dibenarkan oleh syari'at Islam.

Dalam hadis diterangkan bahwa kaum muslimin boleh

${ }^{24}$ Syeikh Muhammad bin Ibrohim bin Abdullah at-Tuaijiri, penerjemah: Najib Junaidi dan Izzuddin Karini, Ensiklopedi Islam Kaffah’. Surabya, Pustaka Yassir, 2011 cet ke tiga, h.1221 
mengadakan penentangan terhadap pemimpin atau mengadakan tindakan bughot kepada pemerintahan yang sah. Sebagaimana telah dijelaskan Dari Ibnu Umar radhiallahu 'anhuma dari Nabi s.a.w., sabdanya: "Wajib atas seorang Muslim untuk mendengar dengan patuh serta mentaati, baik dalam hal yang ia senangi dan yang ia benci, melainkan jikalau ia diperintah untuk sesuatu kemaksiatan. Maka apabila ia diperintah -oleh penguasa pemerintahan- dengan sesuatu kemaksiatan, tidak bolehlah ia mendengarkan perintahnya itu dan tidak boleh pula mentaatinya." (Muttafaq 'alaih)

Dari hadis ini jelaslah bahwa tindakan melawan pemimpin yang memerintahkan kepada kezoliman tidak bertentangan dengan syari'at Islam. Bahkan dengan hadis ini kaum muslimin diperbolehkan untuk mengadakan bughot kepada pemimpin yang sah dengan catatan tindakannya secara Islami. Seperti mengadakan perlawanan dengan tidak membabi buta sehingga tidak merugikan orang banyak, lokasi pemberontakan pun harus ditentukan di tempat yang jauh dari keramaian sehingga tidak menelan korban jiwa lebih banyak lagi seperti pristiwa perang jamal dan perang siffin. .

Selain dua nas di atas yang dijadikan alasan bahwa bughot adalah dindakan yang dibenarkan, maka pristiwa perang jamal dan perang siffin pun dapat dijadikan sebagai alasan. Perang jamal yang dipimpin oleh Siti Aisyah telah mengadakan bughot terhadap pemerintahan yang sah di Madinah. Jika tindakan bughot ini tidak dibenarkan dalam syari' at Islam, lantas posisi Aisyah di akhirat bagaiman, bukankah allah swt. telah menjanjikan kepada setia Istri Rosulullah Muhammad saw. akan masuk surga. Begitu juga dengan perang siffin yang dipimpin oleh Mu'awiyah bin Abi Sofyan juga telah mengadakan bughot terhadap pemerintahan yang sah di Madinah. Mu'awiyah adalah sahabat rosul yang masuk dalam katagori sahabat yang dido'akan oleh Rosul akan masuk surga.

\section{Penutup}

Buhgot adalah tindakan kekerasan yang dapat memadhratkan orang banyak. Karenanya harus ada langkah-langkah yang dapat meminimilisasi kemadharatan tersebut. Seperti mengirim delegasi kepada kelompok bughot untuk mengadakan ishlah serta menanyakan 
kenapa mereka melakukan bughot. Hal ini dilakukan untuk mememberi kesadaran kepada ahli bughot, hingga akhirnya mereka mau kembali untuk taat kepada pemimpin serta dapat melaksanakan kewajiban sebagai rakyat.

Jika tindakan ishlah seperti tersebut tidak berhasil maka langkah selanjutnya adalah menginformasikan kepada mereka bahwa pihak pemerintah yang ah akan mengadakan serangan dan menyatakan perang terhadap ahli bughot. Kemudian menentukan kapan akan diadakan perang dan di tentukan lokasi peperangannya. Dengan ketentuan lokasinya jauh dari keramaian. Mereka yang tertawan harus diperlakukan dengan baik, karena mereka tidak sama statusnya dengan orang kafir.

Pada penutupan ini penulis ingin memaparka sekilas bahwa dalam ilmu ushul fiqh dijelaskan tentang dalil atau nas. Dalil itu kadang bersifat qot'i kadang bersifat zonni. Mayoritas ulama berpendapat bahwa dalil qot'i itu harus diikuti dan diamalkan dan ulama sepakat bahwa dalil zonni itu bersipat alternatif dan tidak mengikat.

Dalam ayat dan hadis tentang bughot memilki sipat zonniyah, zonniyah dilalah, karenanya ulama telah berbeda pendapat dalam menentukan hukum dan yang berhubungan dengan bughot. Namun kalau boleh berbicara tentang kejujuran, penulis ingin mengatakan bahwa pendapat moyoritas ulamalah yang harus dipegang, dengan alasan bahwa tindakan Rosulullah saw. senantiasa mengarah kepada kebersamaan. Juga jika mengikuti pendapat mayoritas itu akan memberi kemudahan, karena tindakannya selalu mengikuti arus bukan melawan arus. Bukankah tindakan yang melawan arus itu akan mendapatkan kesulitan dan bukankah Allah swt. telah berfirman 'Allah swt tidak akan memberi beban kepada manusia melainkan ada kesanggupan'.

Terakhir, jadikanlah perbedaan pendapat sebagai hazanah intelektual dan sebagai ke unifersalan ajaran Islam, namun perbedaan itu jangan dijadikan ajang perdebatan yang berkepanjangan dan ajang untuk memutuskan silaturhim. Rosul bersabda 'Tidak akan masuk surga orang yang gemar memutuskan silaturohim'. 


\section{Pustaka Acuan}

\section{Al-Qur'an al-karim}

Abdullah Muhammad bin Idris, Imam Syafi;i, , Al-Umm. Bairut,Dar al-Fikr.tt.

Auda , Abdul Qodir, at-Tasyri' al Jina'i, Juz ke dua,

Bahnsy , Ahmad Fathy, al-Masuliyah al-Jinaiyah fi al-Figh al-Islamiyah, Dar al-Syuruf, Th.1984.

Dasuqy al-Malikiyah, Hasyiah Dasuqy, Bairut, Dar al-Kitab, , Juz ke enam Th. 1996.

Hanafi,Ahmad, Azas-Azas Hukum Pidana Islam, Bulan Bintang, Jakarta, Th.2002.

Imam al-Ghozaly, al-Wasith fil Mazhab, Dar al-Gislan, 1997.

Imam al-Mawardi, al-Hawi al-Kabir, Dar al-Fikr, Bairut Libanon Juz 16 1994.

Imam Qurthubi, al-Jami' li Ahkamil al-Qur'an, Jilid. 16, Bairut: Dar alKitab, 2000.

Irfan ,Nurul dan Masyrofah, Fiqh Jinayah, Jakarta, PT. Amzah, 2013.

Muanawir, Ahmad Warson, Al-Munawwir Kamus Bahasa Arab-Indonesia, Yogyakarta, 1984.

Rahmat Hakim, Hukum Pidana Islam, Bandung, Pustaka Setia, 2000.

Syafi'i, Muqoronatil Mazahib Al-Arba'ah Wa Mazhab Ja'fari Fil Hudud Wal Qisos Wa Tathbuquha Fi Indonesia.tth

Syeikh Muhammad bin Ibrohim bin Abdullah at-Tuaijiri, Penj, Najib Junaidi dan Izzuddin Karini, Ensiklopedi Islam Kaffah'. Cetakan ke tiga, Surabaya, Pustaka Yassir, 2011.

Yunus, Muhammad, Kamus Bahasa Arab, Jakarta, Hidakarya Agung, 1989.

Syeikh Nawawi, Mahyuddin, al-Majmu' syarah muhajjab li Syairoji, Jeddah-Mamlakah al-“arabiyah al-Sa'udiyah, Maktabah al-Irsyad, Jiddah-Mamlakah al-“arabiyah al-Sa'udiyah, Juz. 21 ttth. 
220 Syafi'i

Syiekh al-'Alamah Mansur bin Yunus al-Hanabilah, Kasyaful Qina Matan al-iqna' Bairut, Dar al-Fikr, 1983.

Zuhaily, Wahbah Zuhaily, al-figh al-Islami wa Adillatuha, Bairut, Darul Fikr, 1989. 